\title{
A liquid supplement of SynerMax and cane molasses for lactating dairy cows in semiconfinement ${ }^{1,2}$
}

\author{
Paul F. Randel ${ }^{3}$ and Jaime R. Moyáa \\ J. Agric. Univ. P.R. 87(3-4):137-147 (2003)
}

\begin{abstract}
Eighteen Holstein cows of approximately $550 \mathrm{~kg}$ mean live weight (LW), and $57 \pm 24$ days in milk at the start, were divided into six groups of three each for use in a single-reversal design, with two 5-wk experimental periods, to compare two treatments: T1, including a liquid feed ( $85 \%$ SynerMax ${ }^{5}: 15 \%$ cane molasses) offered in lick-wheel tanks to three groups between 7:00 a.m. and 2:00 p.m. (1.7-kg daily intake), plus a concentrate of solid ingredients (theoretically $1.8 \mathrm{Mcal} \mathrm{NEL} / \mathrm{kg}, 16 \%$ crude protein) fed individually according to milk yield, a small offering of grass hay ( $<3 \mathrm{~kg}$ consumed daily), and rotational grazing at night in four paddocks on mixed tropical grasses; T2, as in T1 but without liquid feed, rather including a larger concentrate allowance (10.5- vs. 11.6-kg intake). Mean results obtained with T1 and T2, respectively: daily milk yield, $22.45 \mathrm{vs} .22 .55 \mathrm{~kg}$; milk fat percentage, 3.03 vs. 2.94; milk protein percentage, 2.68 vs. $2.76(P<0.01)$. Intakes of dry matter (DM) from high-energy supplements (solid concentrate plus liquid feed) were 10.2 vs. $10.3 \mathrm{~kg}$, respectively. Daily DM intake from grazed forage by cows of both treatments in common pastures was estimated by a disk-drop method as $9.31 \pm 2.68 \mathrm{~kg}$. It is concluded that the liquid feed, when constituting 4 or $5 \%$ of total dietary DM, had a feeding value equal to that of the solid concentrate on a DM basis, but no synergistic effect was substantiated.
\end{abstract}

Key words: Streptomyces solubles, liquid supplement, lactating cows, milk yield, milk composition

\section{RESUMEN}

Un alimento suplementario de SynerMax ${ }^{\circledR}$ y melaza para vacas lactantes en semiconfinamiento

${ }^{1}$ Manuscript submitted to Editorial Board 1 April 2003.

${ }^{2}$ Financial support for this project and material aid in the form of liquid ingredients were provided by Abbott Laboratories, Inc.

${ }^{3}$ Animal Nutritionist, Animal Industry Department, Mayagüez Campus, UPR.

${ }^{4}$ Former Assistant Researcher, Animal Industry Department.

${ }^{5}$ Registered trademark of Abbott Laboratories, Inc. Trade names in this publication are used only to provide specific information. Mention of a trade name does not constitute a warranty of equipment or materials by the Agricultural Experiment Station of the University of Puerto Rico, nor is this mention a statement of preference over other equipment or materials. 
Se usaron 18 vacas Holstein de peso vivo medio aproximado de $550 \mathrm{~kg} \mathrm{y}$ $57 \pm 24$ días postparto al comienzo, divididas entre seis grupos de tres animales, en un diseño de reversión sencilla con dos períodos experimentales de cinco semanas. Se compararon dos tratamientos: T1, un alimento líquido (85\% SynerMax: 15\% melaza de caña) ofrecido en tanques con ruedas de lameo a tres grupos entre las 7:00 am y 2:00 pm (1.7 kg de consumo diario), además de un concentrado basado en ingredientes sólidos (teóricamente $1.8 \mathrm{Mcal} \mathrm{ENL} / \mathrm{kg}, 16 \%$ proteína bruta) suplido individualmente según la producción de leche, un pequeño aporte de heno de gramíneas ( $<3 \mathrm{~kg} /$ día consumidos) y pastoreo nocturno rotacional en cuatro predios con gramíneas tropicales mezcladas; T2, igual a T1 pero sin alimento líquido, e incluyendo una mayor asignación de concentrado (10.5 vs. $11.6 \mathrm{~kg}$ consumidos). Los resultados medios obtenidos con T1 y $\mathrm{T} 2$ fueron, respectivamente: leche diaria, 22.45 vs. $22.55 \mathrm{~kg}$; porcentaje de grasa, 3.03 vs. 2.94 y de proteína en la leche, 2.68 vs. $2.76(P<0.01)$. El consumo de materia seca (MS) procedente de suplementos de alta concentración energética (sólido más líquido) fue 10.2 vs. $10.3 \mathrm{~kg}$. El consumo diario de MS en forraje pastoreado por las vacas de ambos tratamientos en predios comunes fue estimado por un método de caída de disco en $9.31 \pm 2.68 \mathrm{~kg}$. Se concluye que el alimento líquido, al constituir unos 4 a $5 \%$ de la MS dietética total, tuvo un valor alimentario igual al concentrado en base seca, pero no se comprobó un efecto sinergético.

\section{INTRODUCTION}

Synermax is the name of a co-product derived from the industrial fermentation used to manufacture erythromycin at the operations of Abbott Laboratories in North Chicago, IL, and Barceloneta, PR. This industrial process yields a final stable material with a DM content of 49\% and specific gravity of 1.17 (Abbott Laboratories, 2000). This coproduct replaced the former less concentrated by-product known as Liquid Streptomyces Solubles (LSS $\circledast$ ) that contained about $30 \%$ DM (Abbott Laboratories, 1998).

On the North American Continent LSS and SynerMax have been used mainly in poultry feeds. Extensive feeding trial data and practical experience in past years supported the claim that LSS had a beneficial effect in poultry nutrition beyond its contribution of known nutrients (energy and protein). This beneficial effect was ascribed to unidentified fermentation factors. Recent data indicate a similar benefit for SynerMax. In a massive trial with layer hens in high-rise houses, the birds in one house were fed a diet in which $0.5 \%$ of SynerMax was added in partial substitution for maize; these hens produced more eggs, used less feed per unit of egg weight and had lower mortality than controls in a second house (Anonymous, 2002). In a series of experiments with broilers, diets with addition of $0.5 \%$ SynerMax resulted in significantly improved livability, feed conversion efficiency and breast meat yield relative to the control diet in some cases; the $1.0 \%$ level of addition sometimes significantly benefited body weight (Kidd et al., 2002; Fidler et al., 2002). 
A different situation exists in Puerto Rico, where LSS was marketed in mixture with cane molasses as a liquid cattle feed, under the trade name Solub Mol, for more than 20 years until mid 2002 when it was no longer available. The new co-product is also destined mainly to the dairy cattle market. In preliminary animal acceptance testing, dairy heifers given first a choice between pure LSS and Solub Mol and subsequently a choice between pure SynerMax and Solub Mol, as supplements to pasture, ate much more of the Solub Mol in both cases, but SynerMax was better accepted than pure LSS (Christman, 2000). In planning further research, it was deemed of interest to determine whether a synergistic effect of SynerMax, like that seen in poultry, might also occur in feeding lactating cows. The present experiment was a step in this direction. An 85:15 mixture of SynerMax and molasses was offered free choice as a liquid supplement to cows managed in semiconfinement and fed a diet including grazing but also intensive concentrate feeding as the principal energy source, all of which is typical of many local dairy herds (Ruiz et al., 2001).

\section{MATERIALS AND METHODS}

The experiment utilized 18 lactating Holstein cows selected from among those most recently calved ( $57 \pm 24$ days postpartum) of the Lajas Substation herd. Their mean daily milk yield immediately before starting the experiment was $22.7 \pm 3.8 \mathrm{~kg}$. Two were first lactation cows and the remaining 16 were in second or later lactation. The animals were divided into six groups of three each, in the attempt to make the groups as nearly alike as possible in milk production. Equalization of days in milk was a secondary consideration in grouping. Nine cows belonging to groups 1,3 and 5 (initially 52 mean days in milk) received one treatment and the remaining nine (groups 2, 4, and 6; 61 days in milk) received the other treatment in each of the two periods (single reversal design). The periods were of 5 -wk duration, divided into a 2 -wk adjustment phase and a 3-wk comparison phase.

Treatment T1 included a liquid feed offered in lick-wheel tanks during the interval between daily a.m. and p.m. milkings, in addition to a solid concentrate fed according to individual milk production, and small offerings of grass hay ( $\leq 4 \mathrm{~kg} / \mathrm{head})$ to the confined groups in hay racks, and grazing during late afternoon and at night. Treatment T2 was like T1 except that it excluded the liquid feed and incorporated a larger allowance of solid concentrate. T2 cows received $1 \mathrm{~kg}$ of this concentrate per $2 \mathrm{~kg}$ of milk produced, whereas $\mathrm{T} 1$ cows usually received 1 $\mathrm{kg}$ less daily than the amount of concentrate calculated as the said ratio. The purpose of long hay inclusion was to provide rumen-effective 
fiber during the hours of intensive concentrate consumption, but the hay was not of adequate quality to warrant its use as a larger proportion of the diet.

The daily management routine was as follows: Early in the morning cows were brought from pasture for the a.m. milking and then placed in stanchions to receive their first daily portion of solid concentrate. Groups assigned to T1 were placed in three spacious unpaved corrals, each having a small saran-shaded area, water trough, hay rack and lick-wheel tank. The nine animals assigned to T2 were moved to a single tree-shaded corral with water supply and hayrack. Near midday only the T2 cows returned to the stanchion barn to receive a second daily meal of solid concentrate, which was intended to compensate for the lack of liquid feed in T2. After the p.m. milking the cows of both treatments received their final daily portion of solid concentrate and then returned to pasture.

Individual milk samples were obtained from four consecutive milkings once during each of the comparison phases. The refrigerated samples were transported to the DHIA Laboratory of Puerto Rico where they were analyzed for contents of fat and protein.

The liquid feed used in T1 was a 85\%:15\% mixture of SynerMax and cane molasses thoroughly beaten together. This liquid feed was taken from a one-ton pallet tank during the first seven weeks of the experiment, and from two 55-gallon drums during the final three weeks. The pallet tank had been sent from the Abbott factory in Illinois several months earlier and stored outdoors exposed to the sun. However, its contents were well preserved. The drums contained fresh material produced locally in Barceloneta. A single drum provided sufficient molasses to complete the experiment. A sample of liquid from each of these sources and of the solid concentrate and hay were sent for analysis to Dairy One Forage Laboratory in Ithaca, NY. Table 1 gives the percentage crude protein (CP) and neutral detergent fiber (NDF) and mineral contents of these materials.

TABLE 1.-Protein, fiber and mineral contents of the feeds used in the experiment on a dry basis.

\begin{tabular}{lrrrrccccc}
\hline & CP1 & NDF & ADF & Ca & P & Mg & K & Na & S \\
\hline SynerMax & 34.0 & 6.8 & 1.8 & 0.35 & 0.48 & 0.40 & 1.57 & 3.92 & 4.26 \\
Cane Molasses & 2.2 & 1.0 & 0.3 & 0.85 & 0.04 & 0.30 & 2.36 & 0.12 & 0.51 \\
Solid Concentrate & 19.0 & 17.4 & 6.1 & 0.70 & 0.77 & 0.31 & 1.13 & 0.30 & 0.19 \\
Grass Hay & 6.2 & 73.5 & 44.9 & 0.50 & 0.36 & 0.25 & 1.22 & 0.03 & 0.15 \\
\hline
\end{tabular}

${ }^{1} \mathrm{CP}=$ crude protein; $\mathrm{NDF}=$ neutral detergent fiber; $\mathrm{ADF}=$ acid detergent fiber. 
The solid concentrate was prepared at the Lajas Experiment Station and had the following percentage formula: ground yellow maize, 51.5; partially pelleted wheat middlings, 20.0 ; soybean meal, 17.9; rice bran, 5.0 ; whole cottonseed with lint, 4.0 ; ground limestone, 0.75 ; salt. 0.5 ; phosphate supplement, 0.3 ; vitamin supplement, 0.05 . It was calculated to contain $1.8 \mathrm{Mcal} / \mathrm{kg}$ of net energy for lactation (NRC, 1989) and $16.0 \% \mathrm{CP}$. Baled grass hay was obtained in various small lots and was not very uniform. Daily hay offerings per group varied somewhat with intake, but never exceeded $4 \mathrm{~kg}$ per head.

Four 1-ha paddocks supporting swards of mixed grasses were grazed rotationally by the experimental animals. Each paddock was used for five days and then rested for 15 days per 20-day grazing cycle. Synthetic fertilizer was applied to the pastures at the rate of 68,23 and $45 \mathrm{~kg} / \mathrm{ha}$ of $\mathrm{N}, \mathrm{P}_{2} \mathrm{O}_{5}$ and $\mathrm{K}_{2} \mathrm{O}$, respectively, shortly before the start of the experiment. A disk drop method (Bransby et al., 1977) was used to estimate the amount of herbage DM present. During the morning of a day when the cattle were to rotate between paddocks, the disk observations and forage sampling for DM determination were done in both the paddock just grazed and the one about to be grazed. Upon completion of the experiment growth of pasture, herbage was measured over five days in the absence of the animals. With these data, herbage DM intake by the grazing animals was estimated.

The experimental data were subjected to a three-factor analysis of variance with one degree of freedom (df) each for treatments and periods. In those criteria in which individual cow data were obtained (milk yield and composition, solid concentrate intake and live weight, LW) there were $17 \mathrm{df}$ for cows and 16 for experimental error, whereas in the remaining criteria involving group feeding there were 5 and $4 \mathrm{df}$ for groups and error, respectively.

\section{RESULTS AND DISCUSSION}

As planned, intake of solid concentrate was less for T1 than T2 by margins of 0.4 and $1.8 \mathrm{~kg}$ daily in periods 1 and 2 , and $1.07 \mathrm{~kg}$ (equivalent to $0.95 \mathrm{~kg} \mathrm{DM}$ ) over the full experiment (Table 2). In T1, group intake of liquid supplement (on a per head basis) was 1.4, 2.0 and 1.68 $\pm 0.20 \mathrm{~kg}$ daily in periods 1 and 2 and overall, respectively (Table 2). The latter value is equivalent to $0.83 \mathrm{~kg}$ DM, which was in substitution for $0.95 \mathrm{~kg} \mathrm{DM}$ from solid concentrate in T2. Estimated intakes of sodium and sulphur from the liquid supplement were 28 and $31 \mathrm{~g}$ daily, respectively, amounts which did not constitute serious overloading of the animals with these inorganic elements. 
TABLE 2.-Intakes of solid concentrate, liquid supplement, total high-energy supplemental dry matter and partial efficiency ratio of milk to supplemental dry matter and live weight.

\begin{tabular}{|c|c|c|c|c|c|c|c|}
\hline \multirow[b]{2}{*}{ Treatment } & \multicolumn{2}{|c|}{ Period 1} & \multicolumn{2}{|c|}{ Period 2} & \multicolumn{2}{|c|}{ Full experiment } & \multirow{2}{*}{$\begin{array}{c}\text { Difference } \\
\text { between } \\
\text { treatments }{ }^{1}(1-2)\end{array}$} \\
\hline & 1 & 2 & 1 & 2 & 1 & 2 & \\
\hline Daily solid concentrate intake (kg) & 11.6 & 12.0 & 9.4 & 11.2 & $10.52 \pm 0.42^{2}$ & $11.59 \pm 0.38$ & $-1.07 * *$ \\
\hline Daily liquid supplement intake (kg) & 1.4 & - & 2.0 & - & $1.68 \pm 0.20$ & - & NA \\
\hline Supplemental DM intake ${ }^{3}(\mathrm{~kg})$ & 11.0 & 10.7 & 9.4 & 10.0 & $10.20 \pm 0.41$ & $10.32 \pm 0.22$ & $-0.12 \mathrm{NS}$ \\
\hline Ratio milk/supplemental DM ${ }^{3}$ & 2.28 & 2.10 & 2.21 & 2.19 & $2.25 \pm 0.02$ & $2.15 \pm 0.04$ & $0.10 \mathrm{NS}$ \\
\hline Supplemental DM intake ${ }^{3}(\mathrm{~kg} / 100 \mathrm{~kg} \mathrm{LW})$ & 2.12 & 1.92 & 1.71 & 1.79 & $1.92 \pm 0.10$ & $1.85 \pm 0.03$ & $0.07 \mathrm{NS}$ \\
\hline Live weight $(\mathrm{kg})$ & 522 & 557 & 548 & 557 & $535 \pm 13$ & $557 \pm 9$ & $-22 \mathrm{NS}$ \\
\hline
\end{tabular}

${ }_{1 * * *}^{*}=$ Significant $(\mathrm{P}<0.01) ; \mathrm{NS}=$ Not significant $(\mathrm{P}>0.05) ; \mathrm{NA}=$ Not applicable.

2Standard error

${ }^{3}$ From solid concentrate plus liquid supplement in Treatment 1; solid concentrate only in Treatment 2. 
In a previous $3 \times 3$ latin square experiment (Randel, 2001) with 39 dry cows of the same herd that received an individual allowance of 1.5 $\mathrm{kg}$ of solid concentrate and were group fed one of three liquid supplements, daily voluntary intake of an $85 \%$ SynerMax: $15 \%$ molasses mixture was $2.69 \mathrm{~kg}$ per head. That amount exceeds the corresponding figure of the present experiment by $1.3 \mathrm{~kg}$. Logically, intensive feeding of solid concentrate in the present study resulted in reduced appetite for liquid supplement. In the previous experiment, intake of Solub Mol (70\% LSS: $30 \%$ molasses) was, at $3.13 \mathrm{~kg}$ daily, higher (not significantly) than that of the $85 \%$ SynerMax: $15 \%$ molasses mixture, whereas pure SynerMax showed a lower $(\mathrm{P}<0.05)$ but still impressive value of $2.49 \mathrm{~kg}$.

Expressing intakes of high-energy supplements (solid and liquid in $\mathrm{T} 1$ and solid concentrate alone in T2), on the DM basis, gives a slightly higher value for T1 in period 1 (by $0.3 \mathrm{~kg}$ ) and for T2 in period 2 (by 0.6 $\mathrm{kg}$ ), whereas the overall mean was a scarce $0.12 \mathrm{~kg} /$ day higher for T2 (Table 2). When expressed per $100 \mathrm{~kg}$ of LW, intake of high-energy supplemental DM was higher for $\mathrm{T} 1$ in period 1 , for $\mathrm{T} 2$ in period 2 , and for T1 overall $(1.92 \pm 0.10$ vs. $1.85 \pm 0.05 \mathrm{~kg})$, but not significantly so (Table 2). Mean LW was higher overall for T2 by a margin $(\mathrm{P}>0.05)$ of $22 \mathrm{~kg}$ over mean LW of T1.

During period 1 daily intake of hay was 2.3 and $2.8 \mathrm{~kg}$ per head in $\mathrm{T} 1$ and T2, respectively, whereas in period 2 these respective means declined to 1.8 and $2.5 \mathrm{~kg}$. Over the full experiment hay consumption was $0.5 \mathrm{~kg}$ higher in T2 (2.1 vs. $2.6 \mathrm{~kg})$, corresponding to DM intakes of 1.85 and $2.29 \mathrm{~kg}$. This variable could not be subjected to analysis of variance because of lack of replication in $\mathrm{T} 2$, since all nine cows ate from the same hayrack. Using data from observations made on four separate dates, we estimate the DM intake of grazed herbage at $9.31 \pm 2.68 \mathrm{~kg}$ (SD). Using this common value for both treatments, we estimated total forage DM intake (pasture plus hay) as $11.2 \mathrm{~kg}$ (T1) and $11.6 \mathrm{~kg}$ (T2). When added to the respective high-energy supplemental DM intakes of 10.2 and $10.3 \mathrm{~kg}$, estimates of 21.4 and $21.9 \mathrm{~kg}$ of total daily DM intake are obtained, equivalent to $4.0 \%$ and $3.9 \%$ of LW. These figures would seem too high, indicating a probable over-estimation of grazed herbage intake. Perhaps the lower limit of estimate, equal to the mean minus one standard deviation (in this case 9.31-2.68 $=6.63 \mathrm{~kg}$ ) would be more reasonable. If this limit is assumed, the corresponding estimates of total DM intake would then be 18.7 and $19.2 \mathrm{~kg}$, equivalent to $3.5 \%$ and $3.45 \%$ of $\mathrm{LW}$ in $\mathrm{T} 1$ and $\mathrm{T} 2$, which fall within the range of realistic values, according to NRC (1989). Based on these assumptions the proportions of dietary DM supplied by high-energy supplements and by forage would be 55:45 (T1) and 54:46 (T2), and the liquid supplement would account for $4.4 \%$ of the DM consumed in T1. 
During the seven days prior to starting the experiment proper, the nine cows that would be assigned to $\mathrm{T} 1$ in the first experimental period produced $23.2 \mathrm{~kg}$ of milk daily, compared to $21.9 \mathrm{~kg}$ for those that would receive T2 first. Thus, the difference in favor of the former was $1.3 \mathrm{~kg}$ although all cows received the same feeding and management. During the 2 -wk adjustment phase of period 1, daily milk yield increased relative to the pre-experimental levels, giving means of 24.9 and $23.1 \mathrm{~kg}$, respectively, for $\mathrm{T} 1$ and $\mathrm{T} 2$, and thus a slightly greater difference of 1.8 $\mathrm{kg}$, than during the pre-experimental week. During the 3-wk comparison phase of period 1, slight additional increases in production occurred relative to that of the adjustment phase, whereas the mean difference between treatments declined to $1.6 \mathrm{~kg}$ ( $25.2 \mathrm{vs} .23 .6 \mathrm{~kg}$, Table 1), a scarce $0.3 \mathrm{~kg}$ above the original pre-experimental difference. Thus, in period 1 very little effect of treatment was evident.

All cows switched treatments at the start of period 2. During the 2wk adjustment phase daily milk yield declined relative to that of the previous three weeks. The cows now on T2 gave a mean of $24.4 \mathrm{~kg}$, whereas those now on $\mathrm{T} 1$ gave $22.8 \mathrm{~kg}$. Thus, the mean difference of 1.6 $\mathrm{kg}$ previously observed between the groups of cows remained unchanged in spite of the change of treatments.

Six days into comparison phase 2 , an unexpected mischance interrupted the experiment. An all day, high-intensity rainstorm caused flooding of the milking parlor, damaged equipment and disrupted the milking routine for several days. This condition resulted in a sharp decline in milk yield of all the experimental cows, and their pre-flooding levels were not completely restored when conditions were once again normal. During the 3 -wk reinitiated comparison phase 2, daily milk output was $21.5 \mathrm{~kg}$ for $\mathrm{T} 2$, and $19.7 \mathrm{~kg}$ for $\mathrm{T} 1$ (Table 3 ). The difference between treatments thus returned to $1.8 \mathrm{~kg}$, where it had stood in adjustment phase 1, but this time in favor of T2. Upon combining both comparison phases, mean milk yield was $22.45 \pm 0.93$ vs. $22.57 \pm 0.73$ $\mathrm{kg}$ daily in $\mathrm{T} 1$ and $\mathrm{T} 2$, respectively, representing a difference of $0.12 \mathrm{~kg}$ (Table 3). In the statistical analysis of milk yield, cows and especially periods constituted the main sources of variance $(P<0.01)$, whereas treatments were far from having a significant effect at $\mathrm{P}=0.05$.

Milk fat percentage was slightly higher for T1 than for T2 in both periods; the mean difference was 0.08 over the full experiment ( $3.03 \pm$ 0.07 vs. $2.95 \pm 0.09$, Table 3 ). In the analysis of this variable, cows constituted the main source of variance $(\mathrm{P}<0.01)$, whereas the effects of treatments and periods were not significant $(P>0.05)$. Milk protein percentage showed the opposite trend with regard to treatments, it was slightly higher for T2 in both periods. Surprisingly, the small mean difference of 0.08 over the full experiment $(2.69 \pm 0.04$ vs. $2.77 \pm 0.04$, 
TABLE 3.-Production of mill and of milk fat and protein.

\begin{tabular}{|c|c|c|c|c|c|c|c|}
\hline \multirow[b]{2}{*}{ Treatment } & \multicolumn{2}{|c|}{ Period 1} & \multicolumn{2}{|c|}{ Period 2} & \multicolumn{2}{|c|}{ Full experiment } & \multirow{2}{*}{$\begin{array}{l}\text { Difference between } \\
\text { treatments }^{1}(1-2)\end{array}$} \\
\hline & 1 & 2 & 1 & 2 & 1 & 2 & \\
\hline Daily milk yield (kg) & 25.2 & 23.6 & 19.7 & 21.5 & $22.45 \pm 0.93^{2}$ & $22.57 \pm 0.73$ & $-0.12 \mathrm{NS}$ \\
\hline Milk fat content (\%) & 3.08 & 2.94 & 2.97 & 2.94 & $3.03 \pm 0.07$ & $2.95 \pm 0.09$ & $0.08 \mathrm{NS}$ \\
\hline Daily fat yield (kg) & 0.776 & 0.695 & 0.584 & 0.632 & $0.680 \pm 0.045$ & $0.663 \pm 0.039$ & $0.017 \mathrm{NS}$ \\
\hline Milk protein content (\%) & 2.62 & 2.67 & 2.77 & 2.85 & $2.69 \pm 0.04$ & $2.77 \pm 0.04$ & $-0.08^{* * *}$ \\
\hline Daily protein yield (kg) & 0.659 & 0.631 & 0.545 & 0.613 & $0.602 \pm 0.023$ & $0.622 \pm 0.016$ & $-0.020 \mathrm{NS}$ \\
\hline
\end{tabular}

${ }_{1 * *}=$ Significant $(\mathrm{P}<0.01)$; NS $=$ Not Significant $(\mathrm{P}>0.05)$.

${ }^{2}$ Standard error. 
Table 3) reached the $\mathrm{P}=0.01$ level of significance, as did the effects of cows and periods. It is noteworthy that the mean differences between treatments in milk fat and protein contents exactly cancel each other. Similarly, milk fat yield slightly favored T1 by a margin of $0.017 \mathrm{~kg}$, whereas milk protein yield showed a $0.020-\mathrm{kg}$ advantage for T2 (Table 3 ), neither being significant at $P=0.05$.

The efficiency ratio of milk produced/high-energy supplemental DM intake, favored T1 in both periods; overall means were $2.25 \pm 0.02$ vs. $2.15 \pm 0.02$ (not a significant difference). Although not supported by statistically significant data under conditions of the present experiment, this relative difference in feed efficiency is of the order of $5 \%$, and thus is similar to efficiency benefits often observed in poultry with these streptomyces fermentation products in commercial practice. However, this is only a speculative suggestion at present pending further experimental data.

It is concluded that replacement of part of the solid concentrates consumed in T2 (0.95 kg DM daily) by $0.83 \mathrm{~kg}$ DM from the SynerMaxmolasses mixture of T1 resulted in similar milk yield and milk composition. A slight advantage in feed efficiency in favor of the treatment with liquid supplementation is a possibility, but additional data would be needed to substantiate this advantage. As a first test of a SynerMaxbased liquid supplement vs. solid concentrate in a dairy ration, the present results indicate that this pharmaceutical coproduct has an equal feed value on the DM basis. However, no synergistic effect of SynerMax in an otherwise high-quality diet was confirmed under the conditions of this experiment.

At present the following economic guideline can be offered: As of September 2003, the cost of farm delivered SolubMax (a commercial liquid feed similar to the SynerMax-molasses mixture tested in this experiment), if paid for promptly, is $\$ 0.845$ per US gallon, (approximately $4.54 \mathrm{~kg}$ ). Assuming a DM content of $50 \%$, the cost per $\mathrm{kg} \mathrm{DM}$ is $\$ 0.37$. Therefore, a commercial solid concentrate of the same nutritive value in the DM (assumed to be $90 \%$ ) would have an equivalent price on the dry basis if it sold for $\$ 0.33 / \mathrm{kg}$, or $\$ 15.00$ per $100 \mathrm{lb}$ (the usual unit of sale in Puerto Rico). Above this price the solid concentrate would be a more expensive source of nutrients than SolubMax.

\section{LITERATURE CITED}

Abbott Laboratories, 2000. SynerMax ${ }^{\circledR}$ Product Data Sheet. Specialty Products Divisions, Abbott Laboratories, North Chicago, IL. Issued June 2, 2000.

Abbott Laboratories, 1998. LSS ${ }^{\circledR}$ Product Data Sheet. Chemical and Agricultural Products Divisions, Abbott Laboratories, North Chicago, IL. Issued Sept. 3, 1998. 
Anonymous, 2002. Commercial layer feeding trial with and without SynerMax ${ }^{\circledR}$. Presented at International Poultry Exposition, Atlanta, GA. Jan. 2002.

Bransby, D. I., A. G. Matches and G. F. Krause, 1977. Disk method for rapid estimation of herbage yield in grazing trials. Agron. J. 69:393.

Christman, A. M., 2000. The use of liquid streptomyces solubles as an alternative concentrate feed for dairy heifers in Puerto Rico. Thesis in fulfillment of requirements of the George H. Cook Scholars Program. Cook College, Rutgers Univ., New Brunswick, NJ.

Fidler, D. J., B. George, C. L. Quarles and M. T. Kidd, 2002. Effect of dietary liquid saccharopolyspora soluble concentrate on broiler performance and carcass traits. $23^{\text {rd }}$ Ann, Mtg. Southern Poultry Science Society (Abstract).

Kidd, M. T., D. J. Fidler, K. B. Koch, B. George and C. L. Quarles, 2002. Impact of liquid saccharopolyspora soluble concentrate on pellet mill throughput and broiler perfor-

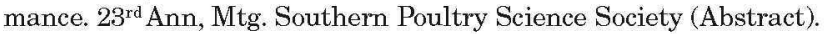

National Research Council, 1989. Nutrient Requirements of Dairy Cattle. National Academy of Sciences, Washington, DC.

Randel, P. F., 2001. Aceptación por bovinos lecheros de tres alimentos líquidos basados en solubles de estreptomicetos preparados por dos procesos distintos. Mem. XVII Reunión ALPA, La Habana. Nov. 2001, pp. 628-630.

Ruiz, T. M., M. López-Beniquez y R. Macchiavelli, 2001. Relación de la carga animal y el uso de alimento concentrado con el porcentaje de grasa láctea y la producción en los hatos lecheros en Puerto Rico. Est. Exp. Agr. Univ. PR Bol. 300. 


\section{BLANK PAGE USED IN PAGE COUNT}

